\title{
DX $5^{+}$NKT cells display phenotypical and functional differences between spleen and liver as well as NK1.1'Balb/c and NK1.1 ${ }^{+}$C57Bl/6 mice
}

Jens M Werner, Elisabeth Busl, Stefan A Farkas, Hans J Schlitt, Edward K Geissler and Matthias Hornung*

\begin{abstract}
Background: Natural killer T cells represent a linkage between innate and adaptive immunity. They are a heterogeneous population of specialized T lymphocytes composed of different subsets. DX $5^{+} \mathrm{NKT}$ cells are characterized by expression of the NK cell marker DX5 in the context of CD3. However, little is known about the phenotype and functional capacity of this unique cell population. Therefore, we investigated the expression of several T cell and NK cell markers, as well as functional parameters in spleen and liver subsets of DX5 $5^{+} \mathrm{NKT}$ cells in NK1.1 $1^{-}$Balb/c mice and compared our findings to NK1.1 $1^{+}$C57Bl/6 mice.

Results: In the spleen 34\% of DX5 ${ }^{+} \mathrm{NKT}$ cells expressed CD62L and they up-regulated the functional receptors CD154 as well as CD178 upon activation. In contrast, only a few liver DX5 ${ }^{+}$NKT cells expressed CD62L, and they did not up-regulate CD154 upon activation. A further difference between spleen and liver subsets was observed in cytokine production. Spleen DX5 ${ }^{+}$NKT cells produced more Th1 cytokines including IL-2, IFN- $\gamma$ and TNF- $\alpha$, while liver DX5 ${ }^{+}$NKT cells secreted more Th2 cytokines (e.g. IL-4) and even the Th17 cytokine, IL-17a. Furthermore, we found inter-strain differences. In NK1.1 $1^{+} \mathrm{C} 57 \mathrm{BI} / 6$ mice DX5 ${ }^{+} \mathrm{NKT}$ cells represented a distinct T cell population expressing less CD4 and more CD8. Accordingly, these cells showed a CD178 and Th2-type functional capacity upon activation.
\end{abstract}

Conclusion: These results show that DX $5^{+}$NKT cells are a heterogeneous population, depending on the dedicated organ and mouse strain, that has diverse functional capacity.

\section{Background}

Natural killer T (NKT) cells represent a small but important subset of $\mathrm{T}$ lymphocytes with characteristics of both $\mathrm{T}$ and NK cells. They have potent immunoregulatory function that reportedly can promote cellmediated immunity to tumors and infectious organisms and, paradoxically, suppress cell-mediated immunity associated with autoimmune disease and allograft rejection [1]. In mice, these cells express NK cell markers such as NK1.1 and CD94, as well as T-cell receptors (TCR) $\alpha / \beta$ with a restricted repertoire $[2,3]$. The invariant $\mathrm{T}$ cell receptor $\alpha$ chain V $\alpha 14-\mathrm{J} \alpha 18$ with a conserved CDR3 region is associated with $\mathrm{V} \beta 8.2, \mathrm{~V} \beta 7$ or Vß2 gene segments [3,4].

\footnotetext{
* Correspondence: matthias.hornung@klinik.uni-regensburg.de Department of Surgery, University Hospital Regensburg, Franz-Josef-StraussAllee 11, 93053 Regensburg, Germany
}

(c) 2011 Werner et al; licensee BioMed Central Ltd. This is an Open Access article distributed under the terms of the Creative Commons Attribution License (http://creativecommons.org/licenses/by/2.0), which permits unrestricted use, distribution, and reproduction in any medium, provided the original work is properly cited.
In contrast to conventional T-lymphocytes, the TCR of NKT cells does not interact with antigens presented by classical major histocompatibility complex (MHC)encoded class I or II molecules. Instead, their TCR recognizes glycolipids presented by CD1d, which is a MHC class-I-like glycoprotein that belongs to a group of CD1 molecules associated with $\beta 2$-microglobulin [5-7]. CD1d is known to present lipids including glycosylceramides and glycosylphosphatidylinositol $[8,9]$. Activation via CD1d initiates the production of both Th1 (IFN) and Th2 cytokines (IL-4, IL-5, IL-13) [10], and increases the cytolytic activity of NKT cells [11].

NKT cells do not represent a homogeneous population. So far, three types of NKT cells have been described. First, there is an invariant Va14-NKT cell (iV $\alpha 14-N K T)$ also called a type I NKT cell or iNKT cell. This group can be further differentiated into $\mathrm{CD}_{4}^{+}$single positive and $\mathrm{CD} 4^{-} \mathrm{CD} 8^{-}$double-negative variants. 
Second, a population of CD1d-reactive NKT cells expressing diverse non-V $\alpha 14$ TCRs, referred to as type II NKT cells, has also been characterized. A third category has been termed NKT-like cells, which are CD1d-independent and express diverse TCRs [2].

Despite many years of NKT cell research, controversy remains about defining these cells. The expression of several surrogate markers, such as NK1.1 in C57Bl/6 mice and CD161 in humans, co-expressed with the $\mathrm{TCR}_{\alpha / \beta}$, have been frequently used for NKT cell identification [2]. There are also NK1.1 ${ }^{+} \mathrm{T}$ cells which do not express the semiinvariant $\mathrm{V} \alpha 14-\mathrm{J} \alpha 18 \mathrm{~T}$ cell receptor and are not CD1d-dependent, excluding their consideration as NKT cells.

A common marker for NKT cells in NK1.1' mice strains is the antibody DX5, which recognizes the $\alpha_{2}$ integrin CD49b [12]. DX5 was initially characterized as a marker for NK cells [13] and more recently DX5 coexpressing $\mathrm{CD}^{+}$lymphocytes have been described [14]. Several studies, including some from our group, revealed evidence for immunoregulatory properties of these cells [15-18]. DX5 ${ }^{+}$NKT cells produce Th1 and Th2 cytokines after stimulation like other NKT cells and seem to play a central role in anti-tumor immunity $[13,19]$. Recently published studies suggest an immune modulatory function of DX $5^{+} \mathrm{NKT}$ cells after bone marrow and solid organ transplantation [20,21]. Although all these studies describe typical characteristics of NKT cells, Pellecci et al. showed that DX $5^{+} \mathrm{T}$ cell numbers were normal in CD $1 \mathrm{~d}^{-/-}$and even in TCR J $\alpha 18^{-/-}$mice [22]. Therefore, it is more likely that $\mathrm{DX} 5^{+} \mathrm{NKT}$ cells belong to the third group of NKT-like cells [22,23].

In the present study we have further characterized $\mathrm{DX}^{+} \mathrm{CD}^{+} \mathrm{T}$ cells referred to as $\mathrm{DX} 5^{+} \mathrm{NKT}$ cells in NK1.1 $1^{-}$(Balb/c) and NK1.1 ${ }^{+}(\mathrm{C} 57 \mathrm{Bl} / 6)$ mice. For this purpose DX $5^{+} \mathrm{NKT}$ cells were isolated from spleen and liver and several $\mathrm{T}$ and NK cell surface markers as well as maturation and activation markers were studied by flow cytometry. Distinct differences could be found between both subsets and between mouse strains.

\section{Results}

T cell marker expression is different between spleen and liver DX5 ${ }^{+} \mathrm{NKT}$ cells

Lymphocytes were isolated from spleen and liver of Balb/c mice by MACS and FACS sorting (Figure 1A). First, expression of different $\mathrm{T}$ cell markers were analyzed to evaluate which subtype of NKT cells the DX5 ${ }^{+} \mathrm{NKT}$ subset belong to. In the spleen of Balb/c mice, 93 $\pm 1.4 \%$ of freshly isolated DX $5^{+} \mathrm{NKT}$ cells expressed $\mathrm{TCR}_{\alpha / \beta}$, with $18 \pm 1.2 \%$ of cells expressing V $\beta 8.1 / 8.2$ (Figure 1B). Surprisingly, most DX $5^{+} \mathrm{NKT}$ cells expressed CD4 (82 $\pm 0.85 \%)$, with $11 \pm 2 \%$ expressing CD8a and CD25. Interestingly, freshly isolated liver DX5
${ }^{+} \mathrm{NKT}$ cells displayed a different receptor pattern. These cells expressed more V $\beta 8.1 / 8.2(36 \pm 3.4 \%, \mathrm{P}=0.0159)$ and less CD4 (67 $\pm 2.6 \%, \mathrm{P}=0.0079)$.

Thus far, surface receptor expression was only examined in freshly isolated cells. Since DX $5^{+} \mathrm{NKT}$ cells display their immunoregulating function especially upon activation [22], expression patterns after stimulation were analyzed. For this purpose, splenic and hepatic mononuclear cells were stimulated for 4 hours with anti-CD3 and anti-CD28 antibodies. Activation of spleen DX $5^{+} \mathrm{NKT}$ cells from Balb/c mice (Figure $1 \mathrm{C}$ ) resulted in a down-regulation of $\mathrm{TCR}_{\alpha / \beta}(90 \pm 2 \%$ vs. $51 \pm 2 \%$, P $=0.004)$ and an up-regulation of CD25 (14 $\pm 2.6 \%$ vs. $27 \pm 3 \%, \mathrm{P}=0.0411)$. However, stimulation had little effect on liver derived cells of Balb/c mice. DX $5^{+} \mathrm{NKT}$ cells revealed an expression pattern similar to that of freshly isolated cells: there was no down-regulation of $\mathrm{TCR}_{\alpha / \beta}$ in liver derived $\mathrm{DX} 5^{+} \mathrm{NKT}$ cells upon stimulation.

\section{NK cell and activatory markers are expressed differently in spleen and liver DX5 ${ }^{+} \mathrm{NKT}$ cells}

To further characterize the differences between spleen and liver DX $5^{+} \mathrm{NKT}$ cells, specific antibodies were used to detect different NK cell types, as well as maturation and activation markers by flow cytometry. In the spleen of Balb/c mice (Figure 2A) the NK cell marker CD94 was expressed on $8 \pm 1.8 \%$ of DX $5^{+} \mathrm{NKT}$ cells. Again, DX $5^{+} \mathrm{NKT}$ cells in the liver displayed differences. CD94 was expressed on significantly more cells than in the spleen $(22 \pm 3.2 \%, \mathrm{P}=0.0095)$. After $4 \mathrm{~h}$ stimulation, no significant change in the NK cell receptor pattern was observed in splenic or hepatic DX $5^{+} \mathrm{NKT}$ cells. As expected, the NK cell marker NK1.1 was expressed only on very few splenic $(0.5 \pm 0.3 \%)$ and hepatic $(0.8 \pm$ $0.6 \%)$ DX $5^{+} \mathrm{NKT}$ cells (data not shown).

We also analyzed if the distinct phenotype of spleen and liver DX $5^{+} \mathrm{NKT}$ cells was based on differences in the maturation status. Therefore, freshly isolated cells were stained with anti-CD103 and anti-CD62L antibodies (Figure 2B). Spleen DX $5^{+} \mathrm{NKT}$ cells were positive for CD103 in $15 \pm 2.4 \%$ of cells. In contrast, freshly isolated liver DX $5^{+} \mathrm{NKT}$ cells expressed this maturation marker less frequently $(4.5 \pm 1.7 \%, \mathrm{P}=0.014)$. Freshly isolated spleen $\mathrm{DX} 5^{+} \mathrm{NKT}$ cells were even more frequently positive for the maturation marker CD62L (34 \pm $5.5 \%)$ compared to liver DX $5^{+} \mathrm{NKT}$ cells $(3 \pm 2.2 \%, \mathrm{P}=$ $0.0079)$. Upon $4 \mathrm{~h}$ stimulation, liver $\mathrm{DX} 5^{+} \mathrm{NKT}$ cells displayed an increase in CD62L expression $(14 \pm 1.7 \%, \mathrm{P}=$ $0.0317)$, but still significantly less than the spleen subset (36 $\pm 4 \%, P=0.0028)$.

Next, differences in activation markers were evaluated. In freshly isolated DX $5^{+} \mathrm{NKT}$ cells the activation marker CD38 was expressed on approximately $80 \%$ of splenic 

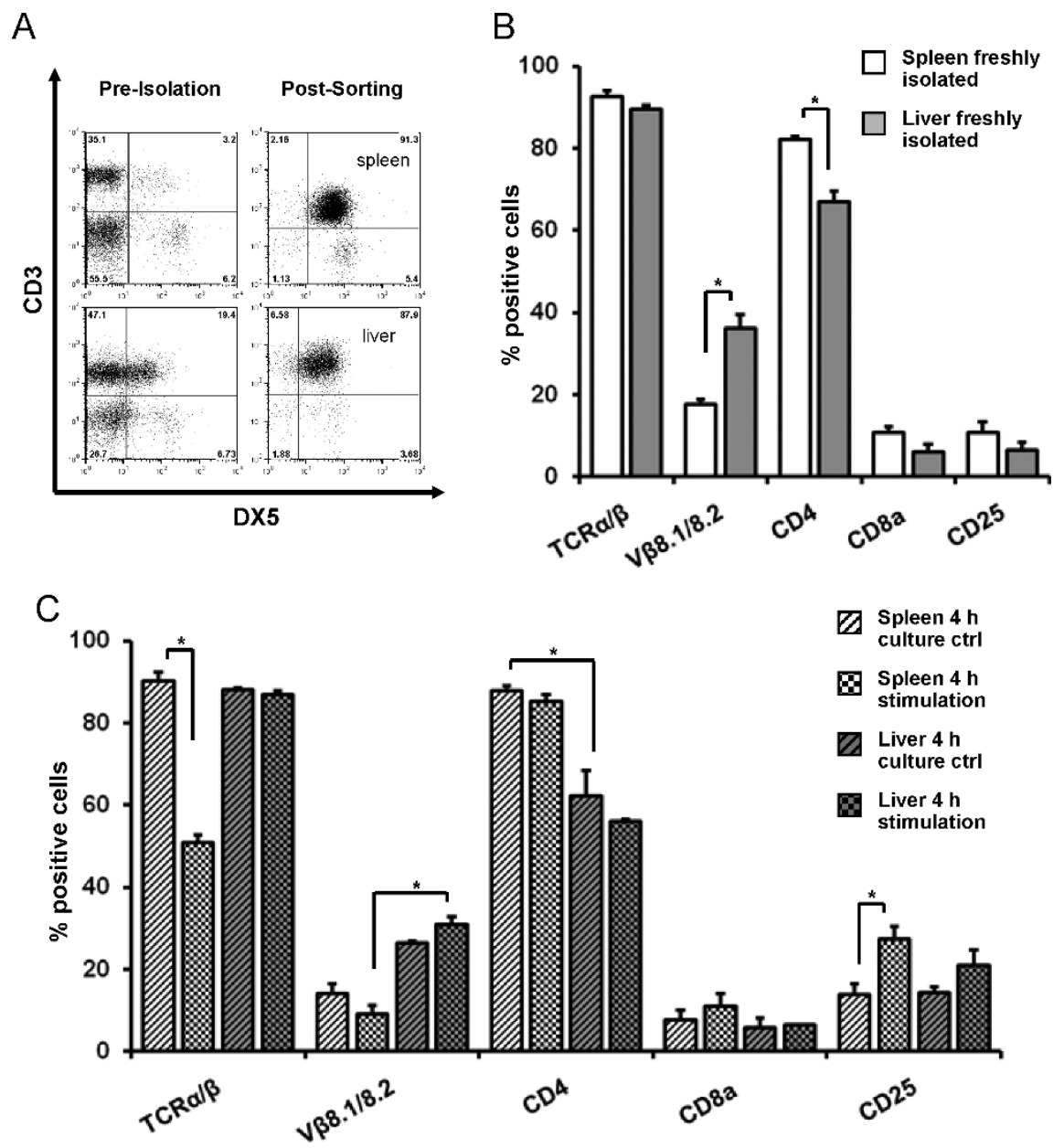

Figure 1 FACS analysis of T cell marker from spleen and liver $\mathrm{CD}^{+} / \mathrm{DX} 5^{+} \mathrm{NKT}$ cells in Balb/c mice. DX5 $5^{+} \mathrm{NKT}$ cells were isolated from spleen and liver of Balb/c mice using MACS and FACS-Sorting. Representative dot plot (A). Expression of different T cell markers revealed distinct subsets in Balb/c mice. In the spleen, more DX5 ${ }^{+} \mathrm{NKT}$ cells appeared CD4 ${ }^{+}$, in the liver, they expressed more V $38.1 / 8.2$ (B). Upon $4 \mathrm{~h}$ activation with anti-CD3 and anti-CD28, spleen DX5 ${ }^{+} \mathrm{NKT}$ cells displayed a TCR $\alpha / \beta$ down-regulation, whereas liver DX5+NKT cells did not (C). Results are given as mean + SEM. Experiments were repeated at least three times $(* p<0.05)$.

and hepatic cells and displayed no significant change upon stimulation (data not shown). In contrast, upon 4 $\mathrm{h}$ stimulation, there was a strong up-regulation of the activating marker CD154 ( $3 \pm 2.2 \%$ vs. $39 \pm 5.8 \%, \mathrm{P}=$ 0.0238 ) in spleen DX $5^{+}$NKT cells (Figure $2 \mathrm{C}$ ). However, liver DX $5^{+} \mathrm{NKT}$ cells did not display a similar up-regulation of CD154 $(4 \pm 1 \%, \mathrm{P}=0.0498)$. Another activating marker, CD178, was also not significantly expressed on freshly isolated DX $5^{+} \mathrm{NKT}$ cells, but upon $4 \mathrm{~h}$ stimulation, there was an up-regulation of CD178 in the spleen subset $(2 \pm 1.3 \%$ vs. $19 \pm 1.4 \%, \mathrm{P}=0.0087)$.

\section{Spleen and liver DX5 ${ }^{+} \mathrm{NKT}$ cells display a distinct cytokine} secretion pattern in Balb/c mice

Results thus far suggest distinct phenotypic differences between spleen and liver DX $5^{+} \mathrm{NKT}$ cells. Next, the production of Th1 and Th2 cytokines were compared to further assess functional differences between these subsets. Lymphocytes were isolated from spleen and liver of $\mathrm{Balb} / \mathrm{c}$ mice and cultured for 4,24 or $48 \mathrm{~h}$ in the presence of anti-CD3 and anti-CD28 antibodies. The cells were additionally incubated with PMA, ionomycin and GolgiPlug for intracellular cytokine staining.

As shown in Figure 3, we first stained for Th1 cytokines such as IL-2, IFN- $\gamma$ and TNF $\alpha$. After 4 h stimulation, $33 \pm 8 \%$ of spleen DX $5^{+} \mathrm{NKT}$ cells produced IL-2. After $24 \mathrm{~h}$, the number of IL-2-producing cells decreased $(0.3 \pm 0.1 \%, P=0.0238)$. As expected, liver DX $5^{+} \mathrm{NKT}$ cells showed a distinct Th1 cytokine profile. After $4 \mathrm{~h}$, lower cell numbers produced IL-2 (11 $\pm 4.4 \%$, $\mathrm{P}=0.049)$ compared to spleen cells. Spleen DX5 $5^{+} \mathrm{NKT}$ cells were also positive for IFN- $\gamma$ after $4 \mathrm{~h}(46 \pm 3.1 \%)$, $24 \mathrm{~h}(40 \pm 4.6 \%)$ and $48 \mathrm{~h}(38 \pm 6.6 \%)$. In contrast, liver DX $5^{+} \mathrm{NKT}$ cells produced less frequently IFN- $\gamma$ after $4 \mathrm{~h}$ 


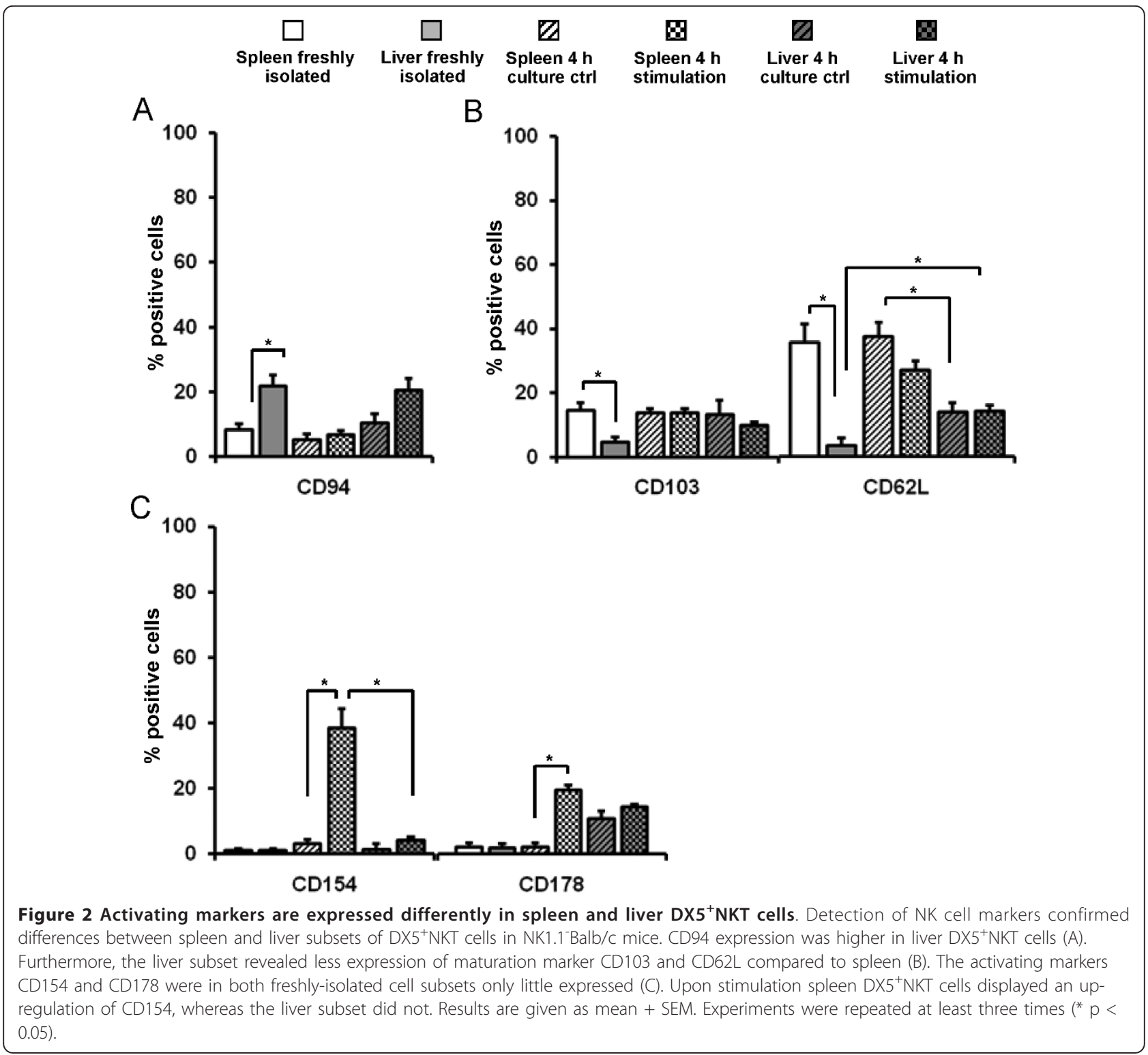

$(24 \pm 2.4 \%, \mathrm{P}=0.0079)$ and $24 \mathrm{~h}(14.5 \pm 2.2 \%, \mathrm{P}=$ $0.0095)$. After $4 \mathrm{~h}$ splenic DX $5^{+} \mathrm{NKT}$ cells produced also $\mathrm{TNF} \alpha(49 \pm 0.6 \%)$. However, the number of TNF $\alpha$-producing cells decreased after $24 \mathrm{~h}(22 \pm 5.1 \%, \mathrm{P}=$ $0.0358)$. Liver DX $5^{+} \mathrm{NKT}$ cells again displayed differences; after $4 \mathrm{~h}$ they produced slightly less TNF $\alpha$ compared to the spleen subset (39 $\pm 4.1 \%$ ) and, after $24 \mathrm{~h}$, the number of TNF $\alpha$-producing cells decreased even more $(4 \pm 1.2 \%, \mathrm{P}=0.0159)$.

Next, Th2 cytokines such as IL-4, IL-6, IL-10 and IL-13 were analyzed. Only very few spleen DX $5^{+} \mathrm{NKT}$ cells produced IL-4 after 4, 24 and $48 \mathrm{~h}$. However, the number of IL-4 positive liver DX $5^{+} \mathrm{NKT}$ cells increased after $48 \mathrm{~h}$ (11 $\pm 1.2 \%, \mathrm{P}=0.0286)$. Neither spleen nor liver DX $5^{+} \mathrm{NKT}$ cells were significantly positive for IL- 6 at any time point (data not shown). Spleen DX $5^{+} \mathrm{NKT}$ cells showed a significant increase in the frequency of IL-10-producing cells after $24 \mathrm{~h}(13 \pm 2.1 \%)$ compared to $4 \mathrm{~h}(0.4 \pm 0.2 \%, \mathrm{P}=0.0187)$, and compared to liver DX $5^{+} \mathrm{NKT}$ cells after $24 \mathrm{~h}$ stimulation $(1 \pm 0.6 \%, P=0.0357)$. In the spleen the number of IL13-producing DX $5^{+} \mathrm{NKT}$ cells significantly increased after $48 \mathrm{~h}$ compared to $4 \mathrm{~h}(20 \pm 3 \%$ vs. $10 \pm 1.2 \%, \mathrm{P}=0.0061)$, whereas in liver the number of IL-13 positive DX $5^{+} \mathrm{NKT}$ cells peaked after $4 \mathrm{~h}$ compared to $24 \mathrm{~h}(16 \pm 2.1 \%$ vs. $3 \pm$ $1.2 \%, \mathrm{P}=0.0286)$. Furthermore, we tested for IL-17a as a Th17-type cytokine. Liver DX $5^{+} \mathrm{NKT}$ cells after $4 \mathrm{~h}$ more frequently produced IL-17a $(7 \pm 1 \%)$ compared to the splenic-derived cells $(1 \pm 0.7 \%, \mathrm{P}=0.0061)$; after $24 \mathrm{~h}$, the frequency of liver-derived IL-17a-producing DX $5^{+} \mathrm{NKT}$ cells decreased $(0.3 \pm 0.3 \%, P=0.286)$. 


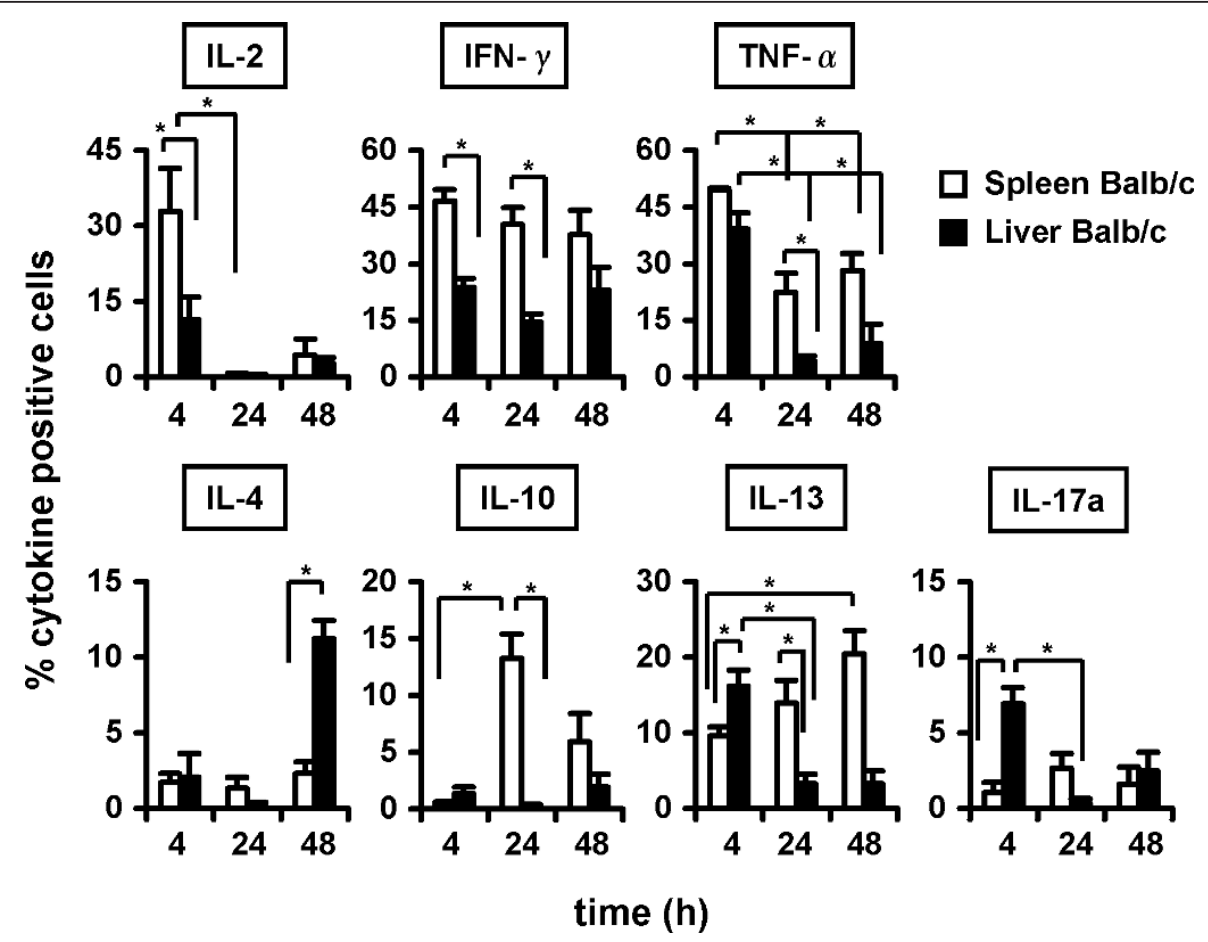

Figure 3 Spleen and liver DX5 ${ }^{+}$NKT cells display a distinct cytokine secretion pattern in Balb/c mice. Isolated DX $5^{+} \mathrm{NKT}$ cells were stimulated with antibodies against CD3 and CD28 in the presence of IL-2 for 4, 24 and 48 h, respectively. Control cells were cultured simultaneously without stimulation. Values were subtracted as background. FACS analysis revealed again distinct differences between spleen and liver subsets of DX5 $5^{+} \mathrm{NKT}$ cells. Results are given as mean + SEM. Experiments were repeated at least three times $\left(^{*} p<0.05\right)$.

NK1.1 ${ }^{+} \mathrm{C} 57 \mathrm{BI} / 6$ mice reveal distinct surface marker expression on DX5 ${ }^{+} \mathrm{NKT}$ cells

Data thus far were obtained using a NK1.1- mouse strain. These findings were compared to a second mouse strain known to express NK1.1, C57Bl/6 mice.. Several $\mathrm{T}$ cell markers were analyzed. A down-regulation of $\mathrm{TCR}_{\alpha / \beta}(65 \pm 4.8 \%$ vs. $89 \pm 2.1 \%, \mathrm{P}=0.01)$ was also observed upon activation of spleen DX $5^{+} \mathrm{NKT}$ cells from C57Bl/6 mice (Figure 4A). Compared to Balb/c, fewer freshly isolated spleen $\mathrm{DX} 5^{+} \mathrm{NKT}$ cells expressed CD4 $(82 \pm 1 \%$ vs. $47 \pm 1.1 \%, \mathrm{P}=0.0043)$, but more expressed CD8a $(11 \pm 1.6 \%$ vs. $32 \pm 0.8 \%, \mathrm{P}=0.0043)$. NK cell markers showed significant differences between both mouse strains (Figure 4B). In C57Bl/6 mice $33 \pm$ $2.8 \%$ of freshly isolated spleen $\mathrm{DX} 5^{+} \mathrm{NKT}$ cells were stained for CD94 $(\mathrm{P}=0.0095)$ and $39 \pm 1 \%$ for NK1.1 $(\mathrm{P}=0.0022)$. Compared to Balb/c mice (Figure $4 \mathrm{C})$, fewer spleen DX $5^{+} \mathrm{NKT}$ cells displayed the maturation marker CD103 (15 $\pm 1.9 \%$ vs. $6 \pm 1.6 \%, \mathrm{P}=0.0030)$, but more expressed CD62L $(33 \pm 5.5 \%$ vs. $47 \pm 1 \%, \mathrm{P}=$ $0.0047)$. In terms of activating markers, both mouse strains showed little expression of CD154 or CD178 in freshly isolated DX $5^{+} \mathrm{NKT}$ cells (Figure 4D). However, upon activation, the up-regulation of CD154 (39 $\pm 5.8 \%$ vs. $13 \pm 1.2 \%, \mathrm{P}=0.0012$ ) was less distinctive in $\mathrm{C} 57 \mathrm{Bl}$ /
6 mice, whereas CD178 expression was similar to Balb/c mice $(19 \pm 1.4 \%$ vs. $18 \pm 1.2 \%)$.

Cytokine production of spleen DX $5^{+}$NKT cells is different in NK1.1'Balb/c and NK1.1 $1^{+}$C57BI/6 mice

Results have already shown distinct phenotypic differences in DX5 ${ }^{+} \mathrm{NKT}$ cells between NK1.1 $1^{-}$and NK1.1 $1^{+}$ mice strains. Next, cytokine production was compared to further assess potential functional differences between these subsets. Lymphocytes were isolated from spleens of Balb/c and C57Bl/6 mice and cultured for 4, 24 or 48 h. As shown in Figure 5 spleen DX $5^{+} \mathrm{NKT}$ cells from the NK $1.1^{+}$mouse strain displayed a distinct Th1 cytokine profile. Compared to NK1.1'Balb/c mice, DX5 ${ }^{+}$NKT cells less often produced IL-2 $(33 \pm 8.6 \%$ vs. $1 \pm$ $0.5 \%, \mathrm{P}=0.0357)$ and TNF- $\alpha(49 \pm 0.6 \%$ vs. $14 \pm 8.8 \%$, $\mathrm{P}=0.0167)$ after $4 \mathrm{~h}$; however, production of IFN- $\gamma$ was similar. In terms of Th2 cytokines, there was also no significant IL-4 production in spleen DX $5^{+} \mathrm{NKT}$ cells from the NK $1.1^{+}$mouse strain. There were some differences in Th2 cytokine production between NK1.1' and $\mathrm{NK} 1.1^{+}$mice. After $24 \mathrm{~h}$, spleen $\mathrm{DX} 5^{+} \mathrm{NKT}$ cells in NK1. $1^{+}$C57Bl/6 mice less frequently produced IL-10 (13 $\pm 2.1 \%$ vs. $1 \pm 0.3 \%, \mathrm{P}=0.0357)$ and IL-13 (14 \pm 2.9 vs. $4 \pm 0.9 \%, P=0.0381)$. The number of splenic- 


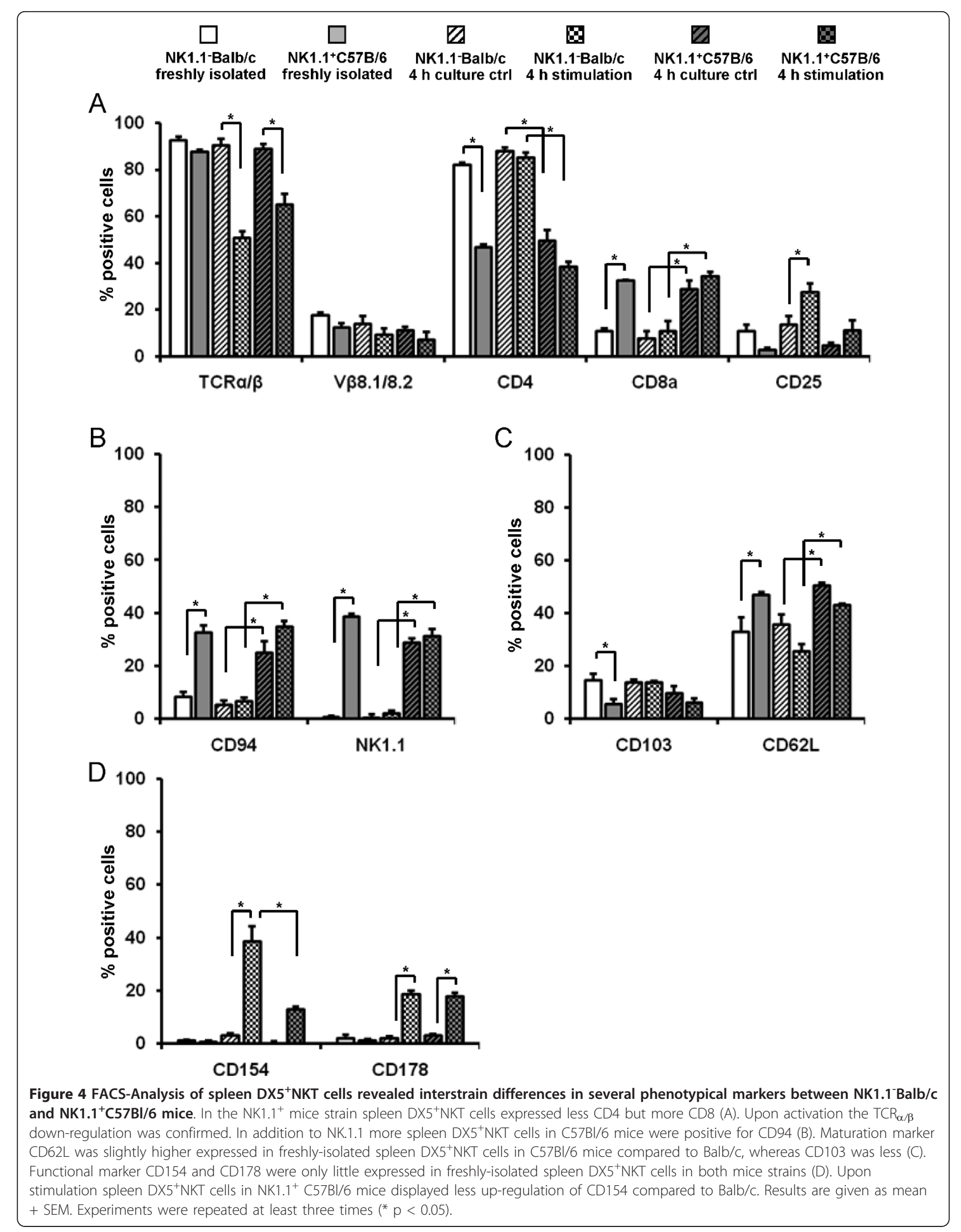




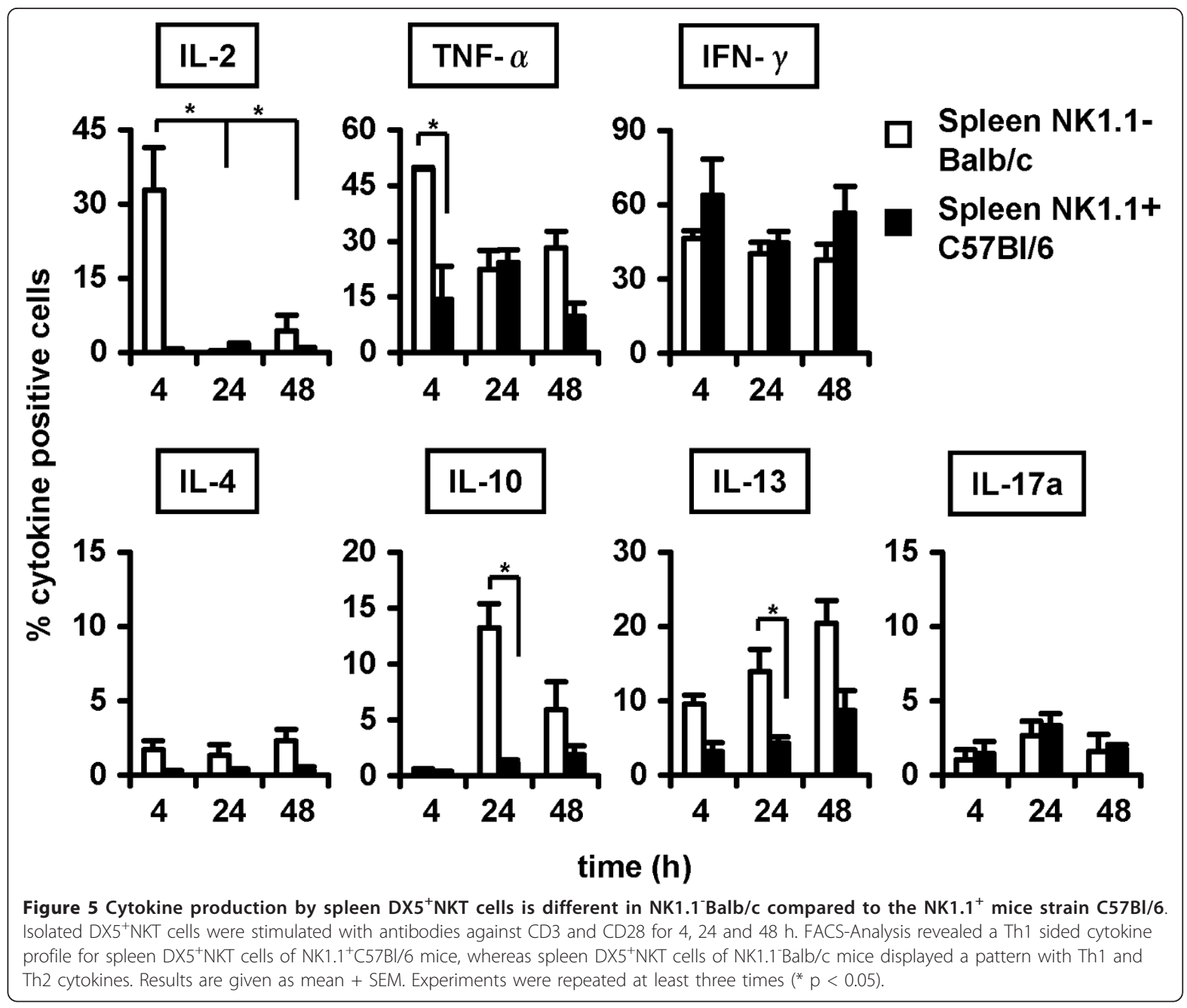

derived IL-17a-producing DX $5^{+} \mathrm{NKT}$ cells was similar in both mouse strains. Only a few spleen DX $5^{+} \mathrm{NKT}$ cells produced IL17a after $4 \mathrm{~h}$ and $24 \mathrm{~h}$.

\section{Discussion}

All freshly isolated DX $5^{+} \mathrm{NKT}$ cells from NK1.1 deficient Balb/c mice were positive for $\mathrm{TCR}_{\alpha / \beta}$, as expected for type III NKT cells [2,3,24]. Most of them additionally expressed CD4, and a few expressed CD8a and CD25. As mentioned in other reports for spleen and thymus [25], a difference between spleen and liver subsets was observed. Liver DX $5^{+} \mathrm{NKT}$ cells expressed less CD4 and CD62L. Since expression of CD62L is associated with naivety or homing to peripheral lymph nodes in iNKTcells [26], and CD4 becomes down-regulated after repeated activation [27], this suggests a higher maturational status of liver $\mathrm{DX} 5^{+} \mathrm{NKT}$ cells in Balb/c mice. This is supported by the finding that V $\beta 8.2$-containing
V $\alpha 14 i$ TCRs in NKT cells have a higher antigen affinity than those containing V $\beta 7$ or V $\beta 2[28,29]$. Consistent with the idea of a negative selection, liver $\mathrm{DX} 5^{+} \mathrm{NKT}$ cells displayed a higher expression of $\mathrm{V} \beta 8.1 / 8.2$.

Upon activation, a down-regulation of $\mathrm{TCR}_{\alpha / \beta}$ was observed in spleen DX $5^{+} \mathrm{NKT}$ cells in Balb/c mice. A decrease of $\mathrm{TCR}_{\alpha / \beta}$-expression was also reported for NK1.1 $1^{+}$NKT cells [30]. Due to a lack of detection, a rapid apoptotic death of this cell was initially claimed upon stimulation [30]. More recently $\mathrm{TCR}_{\alpha / \beta}$-down-regulation in spleen and liver NK1.1 $1^{+} \mathrm{NKT}$ cells of $\mathrm{C} 57 \mathrm{Bl} / 6$ mice was discovered to be the reason for this assumed cell disappearance [31,32]. However, our study does not confirm this finding for liver DX $5^{+} \mathrm{NKT}$ cells in Balb/c mice, supporting evidence that there are distinct subsets of DX $5^{+} \mathrm{NKT}$ cells in the spleen and liver. CD154 expression was also increased upon stimulation. As the ligand of CD40, CD154 represents a co-stimulatory 
molecule and is expressed by activated and regulatory $\mathrm{T}$ cells $[33,34]$. Furthermore, CD178, the ligand of Fas responsible for the extrinsic induction of apoptosis (e.g. expressed on $\mathrm{CD}^{+}$cytotoxic $\mathrm{T}$ cells) was up-regulated [35]. This up-regulation was more evident in spleen than in liver DX $5^{+} \mathrm{NKT}$ cells and is also reported for NK1. $1^{+} \mathrm{NKT}$ cells [36]. Taken together, liver DX $5^{+} \mathrm{NKT}$ cells are more mature and display a different activating phenotype upon stimulation compared to the spleen subset.

Since NKT cells are supposed to link innate and adaptive immunity by rapid secretion of cytokines, including IFN $\gamma$, TNF $\alpha$, IL-4, IL-10, IL-13, GM-CSF and IL-2 $[24,37,38]$, we further assessed differences between spleen and liver DX $5^{+} \mathrm{NKT}$ cells on a functional basis. Fewer liver DX $5^{+} \mathrm{NKT}$ cells in Balb/c mice produced Th1 cytokines such as IL-2, IFN- $\gamma$, and TNF- $\alpha$. In terms of Th2 cytokines, more liver DX $5^{+} \mathrm{NTK}$ cells produced IL-4, but fewer produced IL-10 compared to the spleen subset. Charbonnier et al. described an induction of IL10 production in liver $\mathrm{CD}_{4} 9 \mathrm{~b}^{+} \mathrm{CD}^{+} \mathrm{T}$ cells by immature dendritic cell vaccination [18]. However, we did not confirm this finding for liver DX $5^{+} \mathrm{NKT}$ cells in Balb/c mice after anti-CD3/anti-CD28 stimulation. Collectively, the limited Th1 cytokine secretion upon stimulation confirmed the observation that a different activating phenotype of DX $5^{+} \mathrm{NKT}$ cells exists in the liver of Balb/ c mice.

Recently, type I NKT cells have been shown to be capable of producing IL-17, potentially implicating this cell type in inflammatory conditions $[39,40]$. We showed that a subset of DX $5^{+} \mathrm{NKT}$ cells in the liver of Balb/c mice has to be taken into account as an IL-17 producing cell. These results are consistent with our result regarding a more mature phenotype of liver-derived DX5 ${ }^{+} \mathrm{NKT}$ cells, with a different phenotypical profile upon stimulation compared to the spleen subset.

In $\mathrm{NK} 1.1^{+} \mathrm{C} 57 \mathrm{Bl} / 6$ mice fewer spleen DX $5^{+} \mathrm{NKT}$ cells revealed expression of CD4, but more of CD8a. These findings are consistent with data from Pellici et al., who observed similar differences in $\mathrm{C} 57 \mathrm{Bl} / 6$ mice [22]. In accordance with Conzalez et al., 40-50\% of DX $5^{+} \mathrm{NKT}$ cells express NK1.1 [15]. Taking these results together with the higher CD4 expression in NK1.1-deficient $\mathrm{Balb} / \mathrm{c}$ mice, we suggest that these mice compensate for a reduced number of NK.1.1 $1^{+} \mathrm{NKT}$ cells with a higher prevalence of $\mathrm{CD} 4{ }^{+} \mathrm{DX} 5^{+} \mathrm{NKT}$ cells. In contrast to results from Gonzalez et al. [15], about one-third of these cells in the spleen of $\mathrm{C} 57 \mathrm{Bl} / 6$ mice, and $11 \%$ in Balb/c mice, were $\mathrm{CD}^{+}$.

Upon activation a down-regulation of $\mathrm{TCR}_{\alpha / \beta}$ was observed in spleen DX $5^{+} \mathrm{NKT}$ cells in Balb/c and in $\mathrm{C} 57 \mathrm{Bl} / 6$ mice, as it has been reported for $\mathrm{NK} 1.1^{+} \mathrm{NKT}$ cells [30]. Furthermore, upon a $4 \mathrm{~h}$ stimulation there was a notable up-regulation of CD25 in Balb/c versus $\mathrm{C} 57 \mathrm{Bl} / 6$ mice. CD25, the IL-2 receptor $\alpha$-chain, is proposed to be a phenotypical marker of regulatory $\mathrm{T}$ cells [41-43]. The up-regulation we observed especially for spleen DX $5^{+} \mathrm{NKT}$ cells in Balb/c mice could be either due to activation and increased receptor expression based on the regulatory background of DX $5^{+} \mathrm{NKT}$ cells or due to a natural selection because of a higher apoptotic resistance in $\mathrm{CD} 4{ }^{+} \mathrm{CD} 25^{+} \mathrm{T}$ cells [44]. Another marker for activation on regulatory T cells is CD154 [34]. CD154 expression was increased upon stimulation in spleen DX $5^{+} \mathrm{NKT}$ cells in Balb/c mice, but was significantly less prominent in $\mathrm{C} 57 \mathrm{Bl} / 6$ mice. Upon $4 \mathrm{~h}$ stimulation, CD178 (ligand of Fas) was similarly up-regulated [35] on splenic DX $5^{+} \mathrm{NKT}$ cells in both mice strains. However, after $24 \mathrm{~h}$ stimulation CD178 expression was decreased in Balb/c versus C57Bl/6 mice, and CD154 was further up-regulated in Balb/c, but down-regulated in $\mathrm{C} 57 \mathrm{Bl} / 6$ mice (data not shown). These changes suggest a more regulatory $\mathrm{CD} 4{ }^{+} \mathrm{CD} 25^{+}$phenotype in $\mathrm{NK} 1.1^{-} \mathrm{Balb} / \mathrm{c}$ and a more $\mathrm{CD} 8^{+}$and $\mathrm{CD} 178^{+}$driven cytotoxic component in the NK1.1 ${ }^{+}$C57Bl/6 mouse strain [45].

High IL- 2 production by DX $5^{+} \mathrm{NKT}$ cells in the early phase of activation was observed only in Balb/c mice, further supporting our findings of interstrain differences. Moreover, splenic DX $5^{+} \mathrm{NKT}$ cells in C57Bl/6 mice displayed a more one-sided Th1 cytokine profile, with mostly IFN $\gamma$ and TNF $\alpha$ producing cells, which is also described for $\mathrm{CD}^{+} \mathrm{T}$ cells [46]. DX $5^{+} \mathrm{NKT}$ cells in $\mathrm{Balb} / \mathrm{c}$ mice displayed a more polyfunctional cytokine profile. In the late phase of stimulation, IFN $\gamma$ and TNF $\alpha$ production decreased and IL-10 and IL-13 secretion increased. In contrast to liver $\mathrm{CD} 49 \mathrm{~b}^{+} \mathrm{CD} 4^{+}$cells [18], and supporting our data regarding splenic DX $5^{+} \mathrm{NKT}$ cells, Kassiotis et al. revealed no IL-10 production for

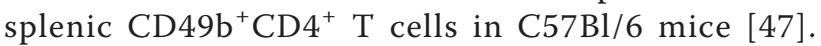
Furthermore, Pellicci et al. could not detect any significant IL-10 production in $\mathrm{DX} 5^{+} \mathrm{TCR}_{\alpha / \beta}{ }^{+} \mathrm{CD} 1 \mathrm{~d}-\mathrm{Tet}^{+}$cells in the same mouse strain [22]. Confirming our finding and giving again evidence for a difference between both mouse strains, we showed a significant increase in IL-10 production after $24 \mathrm{~h}$ stimulation for splenic $\mathrm{DX} 5^{+} \mathrm{NKT}$ cells in Balb/c mice. Taken together, these results suggesting a more one-sided Th1 cytokine production from DX $5^{+} \mathrm{NKT}$ cells in $\mathrm{C} 57 \mathrm{Bl} / 6$ mice confirm their more CD8 and CD178 expressing phenotype.

\section{Conclusions}

In conclusion, our data show that distinct subsets of DX $5^{+} \mathrm{NKT}$ cells exist within NK1.1- Balb/c mice. In the spleen these cells appear more naive with a higher CD62L expression and an up-regulation of CD154 and CD178 upon activation. In contrast, in the liver DX5 
${ }^{+} \mathrm{NKT}$ cells are more mature and display a different regulatory potency upon stimulation. Furthermore, there are remarkable inter-strain differences. In $\mathrm{NK} 1.1^{+}$ C57Bl/6 mice, fewer DX $5^{+} \mathrm{NKT}$ cells are $\mathrm{CD} 4^{+}$and more are $\mathrm{CD}^{+}$, confirming their CD178 and Th1-sided functional behavior upon activation.

\section{Methods}

\section{Cell harvesting and isolation}

All experiments were approved by the institutional animal care committee at the University Hospital Regensburg. Different lymphocytes subsets were purified from splenic or hepatic mononuclear cells isolated from Balb/ c mice or $\mathrm{C} 57 \mathrm{Bl} / 6 \mathrm{NCrl}$ mice (Charles River Laboratories, Wilmington, MA, USA). If necessary, further isolation was performed by magnetic activated cell sorting (MACS; Miltenyi Biotec, Bergisch Gladbach, Germany) or by FACS (FACSAria I, BD Bioscience, San Jose, CA, USA). Briefly, cell suspension of the spleen was prepared by cutting the tissue into small pieces and gently pressing through a $100 \mu \mathrm{m}$ wire mesh. For preparation of the liver the portal vein was flushed with $10 \mathrm{ml}$ sodium chloride until the organ became pale. Then the liver was cut into small parts and passed through a $100 \mu \mathrm{m}$ wire mesh. Hepatic lymphocytes were further isolated by density gradient centrifugation using $80 \%$ and $40 \%$ Percoll (Biochrom, Berlin, Germany). For further isolation, $\mathrm{DX}^{+}$cells were purified using anti-mouse-DX $5^{+}$ MicroBeads (Miltenyi Biotec). Cells were passed through a MACS-column (type LS) attached to a Midi-MACSmagnet (Miltenyi Biotec). DX $5^{+}$cells were labeled with FITC-conjugated anti-mouse CD3 (clone: 17A2, rat IgG2b) and PE-conjugated anti-mouse CD49b (clone: DX5, rat IgM) (all from BD Biosciences) for further $\mathrm{CD}^{+} \mathrm{DX} 5^{+}$enrichment by FACS, and are referred to as DX $5^{+} \mathrm{NKT}$ cells throughout the study.

\section{Antibodies and flow cytometry}

The following reagents were used for cell surface labeling in multiparameter flow cytometric analysis (FACS Calibur, BD Bioscience): FITC or Alexa Fluoar 647-conjugated anti-mouse CD3 (clone: 17A2, rat IgG2b), APC-conjugated anti-mouse-CD4 (clone: GK1.5, rat IgG2b), APCconjugated anti-mouse-CD8a (clone: 53-6.7, rat IgG2a), PE-conjugated anti-mouse-CD38 (clone: 90, rat IgG2a), PE-conjugated anti-mouse-CD49b (clone: DX5, rat IgM), APC-conjugated anti-mouse-CD62L (clone: MEL-14, rat IgG2a), PE-conjugated anti-mouse-CD103 (clone: M290, rat IgG2a), PE-conjugated anti-mouse-CD178 (Fas-Ligand) (clone: MFL3, hamster IgG1), PE-conjugated anti-mouseVß 8.1, 8.2 TCR (clone: MR5-2, rat IgG2a) all BD Biosciences. APC-conjugated anti-mouse-CD49b (clone: DX5, rat IgM), FITC-conjugated anti-mouse-CD49b (clone: DX5, rat IgM) all obtained from Miltenyi Biotec. FITC- conjugated anti-mouse-CD94 (clone: 18d3, rat IgG2a), APC-conjugated anti-mouse-CD154 (CD40L) (clone: MR1, hamster IgG), APC-conjugated anti-mouse-NK1.1 (clone: PK136, mouse IgG2a) all obtained from eBioscience (San Diego, CA, USA). APC-conjugated antimouse-CD25 (clone: PC61 5.3, rat IgG1), FITC-conjugated anti-mouse-TCR $\alpha / \beta$ (clone: HM 3601, hamster IgG) from Caltag (Towcester, UK).

\section{Activation of DX5 $5^{+} \mathrm{NKT}$ cells}

For lymphocyte stimulation, 96 well cell culture plates (Corning costar, Sigma Aldrich) were coated with antimouse-CD3e (Clone: 145-2C11, BD Biosciences) at $10 \mu \mathrm{g} /$ $\mathrm{ml}$ and stored overnight at $4^{\circ} \mathrm{C}$. Wells were washed twice with PBS. And up to $1 \times 10^{6}$ isolated lymphocytes from spleen and liver were plated in $200 \mu \mathrm{l}$ RPMI culture medium (Biochrom). For activation, $5 \mu \mathrm{g} / \mathrm{ml}$ of anti-mouseCD28 (clone: 37.51, BD Biosciences) and 2000 IU/ml IL-2 (Peprotech, Rocky Hill, NJ, USA) were added. Plates were incubated for the indicated time at $37^{\circ} \mathrm{C}$ and $5 \% \mathrm{CO}_{2}$

\section{Intracellular cytokine staining}

$4 \times 10^{5} \mathrm{DX}^{+}$-NKT cells were incubated in $200 \mu \mathrm{l} \mathrm{cul-}$ ture medium in a 96 well plate as mentioned above. Additionally, $50 \mathrm{ng} / \mathrm{ml}$ PMA (InvivoGen, San Diego, CA, USA) was added at the beginning, with $750 \mathrm{ng} / \mathrm{ml}$ ionomycin (Sigma-Aldrich, St. Louis, USA) being added for the last 4h; $1 \mu \mathrm{g} / \mathrm{ml}$ GolgiPlug (BD Bioscience) was added $2 \mathrm{~h}$ before cell harvesting. Culture supernatants were harvested and stored at $-20^{\circ} \mathrm{C}$ for IFN $\gamma$ ELISA. Cells were fixed in $1 \mathrm{ml} \mathrm{Fix/Perm} \mathrm{(eBioscience)} \mathrm{for} 60$ $\min$ at $4^{\circ} \mathrm{C}$. After incubation with permeabilization buffer (eBioscience) cells were stained with PE-conjugated anti-mouse-cytokine Abs (IL-2, clone: JES6-5H4/IL-4, clone: BVD4-1D11/IL-6, clone: MP5-20F3/IL-10, clone: JES5-16E3/IFN $\gamma$, clone: XMG1.2/TNF $\alpha$, clone: MP6$\mathrm{XT} 22$ ) from $\mathrm{BD}$ Bioscience and with PE-conjugated anti-mouse-Abs (IL-13, clone: eBio13A/IL-17a, clone: eBio17B7) and FITC-conjugated anti-mouse-IFN $\gamma$ (clone: XMG1.2) (all eBioscience).

\section{IFN $\gamma$ analysis by Enzyme-Linked Immunosorbent Assay} Stimulation of DX $5^{+} \mathrm{NKT}$ cells was confirmed by IFN $\gamma$ ELISA. IFN $\gamma$ concentration from harvested supernatants was analyzed using a commercially available sandwich ELISA kit (BD Bioscience). Tetramethylbenzidine dihydrochloride was used for detection. ELISA readings were determined by OD scanning at $450 \mathrm{~nm}$ using an Emax precision microplate reader from Molecular Devices (Downingtown, PA, USA).

\section{Statistics}

All in vitro experiments were repeated at least 3 times and data are presented as the mean value \pm SEM. 
Statistical analyses were performed using either a student's t-test or the Mann-Whitney-U-test. Differences were considered significant at $\mathrm{P}<0.05$.

\section{Acknowledgements}

We wish to thank Joachim Schweimer for his excellent technical assistance This work was supported by funds from the "Regensburger Forschungsförderung Medizin (ReForM)".

\section{Authors' contributions}

JMW carried out FACS analysis, participated in the design of the study, data analysis and the preparation of the manuscript. EB carried out isolation of cells and FACS analysis. SAF participated in the design and coordination of the study and helped to draft the manuscript. HJS participated in the design of the study and revised the manuscript and gave important intellectual content. EKG has made substantial contributions to the conception and the design of the study, to the analysis and interpretation of the data and revised the manuscript. MH conceived of the study, and participated in its design and coordination, analyzed the data and drafted the manuscript. All authors read and approved the final manuscript.

Received: 9 January 2011 Accepted: 29 April 2011

Published: 29 April 2011

\section{References}

1. Godfrey DI, Stankovic S, Baxter AG: Raising the NKT cell family. Nat Immunol 11:197-206.

2. Godfrey DI, MacDonald HR, Kronenberg M, Smyth MJ, Van Kaer L: NKT cells: what's in a name? Nat Rev Immunol 2004, 4:231-7.

3. Godfrey DI, Hammond KJ, Poulton LD, Smyth MJ, Baxter AG: NKT cells: facts, functions and fallacies. Immunol Today 2000, 21:573-83.

4. Lantz O, Bendelac A: An invariant T cell receptor alpha chain is used by a unique subset of major histocompatibility complex class I-specific CD4+ and CD4-8- T cells in mice and humans. J Exp Med 1994, 180:1097-106.

5. Brigl M, Brenner MB: CD1: antigen presentation and T cell function. Annu Rev Immunol 2004, 22:817-90.

6. Burdin N, Brossay L, Degano M, lijima H, Gui M, Wilson IA, Kronenberg M: Structural requirements for antigen presentation by mouse CD1. Proc Natl Acad Sci USA 2000, 97:10156-61.

7. Burdin N, Kronenberg M: CD1-mediated immune responses to glycolipids. Curr Opin Immunol 1999, 11:326-31.

8. Joyce S, Woods AS, Yewdell JW, Bennink JR, De Silva AD, Boesteanu A, Balk SP, Cotter RJ, Brutkiewicz RR: Natural ligand of mouse CD1d1: cellular glycosylphosphatidylinositol. Science 1998, 279:1541-4.

9. Kawano T, Tanaka Y, Shimizu E, Kaneko Y, Kamata N, Sato H, Osada H, Sekiya S, Nakayama T, Taniguchi M: A novel recognition motif of human NKT antigen receptor for a glycolipid ligand. Int Immunol 1999, 11:881-7.

10. Benlagha $K$, Weiss A, Beavis A, Teyton $L$, Bendelac A: In vivo identification of glycolipid antigen-specific T cells using fluorescent CD1d tetramers. J Exp Med 2000, 191:1895-903.

11. Cui J, Shin T, Kawano T, Sato H, Kondo E, Toura I, Kaneko Y, Koseki H, Kanno M, Taniguchi M: Requirement for Valpha14 NKT cells in IL-12mediated rejection of tumors. Science 1997, 278:1623-6.

12. Arase H, Saito T, Phillips JH, Lanier LL: Cutting edge: the mouse NK cellassociated antigen recognized by DX5 monoclonal antibody is CD49b (alpha 2 integrin, very late antigen-2). J Immunol 2001, 167:1141-4.

13. Moodycliffe AM, Maiti S, Ullrich SE: Splenic NK1.1-negative, TCR alpha beta intermediate CD4+ T cells exist in naive NK1.1 allelic positive and negative mice, with the capacity to rapidly secrete large amounts of IL-4 and IFN-gamma upon primary TCR stimulation. J Immunol 1999, 162:5156-63.

14. Ortaldo JR, Winkler-Pickett R, Mason AT, Mason LH: The Ly-49 family: regulation of cytotoxicity and cytokine production in murine $\mathrm{CD} 3+$ cells. J Immunol 1998, 160:1158-65.

15. Gonzalez A, Andre-Schmutz I, Carnaud C, Mathis D, Benoist C: Damage control, rather than unresponsiveness, effected by protective DX5+ T cells in autoimmune diabetes. Nat Immunol 2001, 2:1117-25.

16. Adachi K, Tsutsui H, Seki E, Nakano H, Takeda K, Okumura K, Van Kaer L, Nakanishi K: Contribution of CD1d-unrestricted hepatic DX5+ NKT cells to liver injury in Plasmodium berghei-parasitized erythrocyte-injected mice. Int Immunol 2004, 16:787-98.

17. Hornung M, Farkas SA, Sattler C, Schlitt HJ, Geissler EK: DX5+ NKT cells induce the death of colitis-associated cells: involvement of programmed death ligand-1. Eur J Immunol 2006, 36:1210-21.

18. Charbonnier LM, van Duivenvoorde LM, Apparailly F, Cantos C, Han WG, Noel D, Duperray C, Huizinga TW, Toes RE, Jorgensen C, et al: Immature dendritic cells suppress collagen-induced arthritis by in vivo expansion of CD49b+ regulatory T cells. J Immunol 2006, 177:3806-13.

19. Osada T, Nagawa H, Shibata Y: Tumor-infiltrating effector cells of alphagalactosylceramide-induced antitumor immunity in metastatic liver tumor. I Immune Based Ther Vaccines 2004, 2:7.

20. Lan F, Zeng D, Higuchi M, Higgins JP, Strober S: Host conditioning with total lymphoid irradiation and antithymocyte globulin prevents graftversus-host disease: the role of $\mathrm{CD} 1$-reactive natural killer T cells. Biol Blood Marrow Transplant 2003, 9:355-63.

21. Margalit M, Ilan $Y$, Ohana M, Safadi R, Alper R, Sherman $Y$, Doviner $V$, Rabbani E, Engelhardt D, Nagler A: Adoptive transfer of small numbers of DX5+ cells alleviates graft-versus-host disease in a murine model of semiallogeneic bone marrow transplantation: a potential role for NKT lymphocytes. Bone Marrow Transplant 2005, 35:191-7.

22. Pellicci DG, Hammond K, Coquet J, Kyparissoudis K, Brooks AG, Kedzierska K, Keating R, Turner S, Berzins S, Smyth MJ, et al: DX5/CD49bpositive T cells are not synonymous with CD1d-dependent NKT cells. J Immunol 2005, 175:4416-25.

23. Wingender $\mathrm{G}$, Kronenberg M: Role of NKT cells in the digestive system. IV. The role of canonical natural killer T cells in mucosal immunity and inflammation. Am J Physiol Gastrointest Liver Physiol 2008, 294:G1-8.

24. Kronenberg M, Gapin L: The unconventional lifestyle of NKT cells. Nat Rev Immunol 2002, 2:557-68.

25. Yang Y, Ueno A, Bao M, Wang Z, Im JS, Porcelli S, Yoon JW: Control of NKT cell differentiation by tissue-specific microenvironments. J Immunol 2003, 171:5913-20.

26. Kim CH, Johnston B, Butcher EC: Trafficking machinery of NKT cells: shared and differential chemokine receptor expression among $V$ alpha 24(+)V beta 11(+) NKT cell subsets with distinct cytokine-producing capacity. Blood 2002, 100:11-6.

27. Chen H, Huang H, Paul WE: NK1.1+ CD4+ T cells lose NK1.1 expression upon in vitro activation. J Immunol 1997, 158:5112-9.

28. Schumann J, Voyle RB, Wei BY, MacDonald HR: Cutting edge: influence of the TCR $V$ beta domain on the avidity of CD1d:alpha-galactosylceramide binding by invariant $\mathrm{V}$ alpha 14 NKT cells. J Immunol 2003, 170:5815-9.

29. Chun T, Page MJ, Gapin L, Matsuda JL, Xu H, Nguyen H, Kang HS, Stanic AK, Joyce S, Koltun WA, et al: CD1d-expressing dendritic cells but not thymic epithelial cells can mediate negative selection of NKT cells. J Exp Med 2003, 197:907-18.

30. Eberl G, MacDonald HR: Rapid death and regeneration of NKT cells in anti-CD3epsilon- or IL-12-treated mice: a major role for bone marrow in NKT cell homeostasis. Immunity 1998, 9:345-53.

31. Wilson MT, Johansson C, Olivares-Villagomez D, Singh AK, Stanic AK, Wang $C R$, Joyce $S$, Wick MJ, Van Kaer L: The response of natural killer T cells to glycolipid antigens is characterized by surface receptor downmodulation and expansion. Proc Natl Acad Sci USA 2003, 100:10913-8.

32. Harada M, Seino K, Wakao H, Sakata S, Ishizuka Y, Ito T, Kojo S, Nakayama T, Taniguchi M: Down-regulation of the invariant Valpha14 antigen receptor in NKT cells upon activation. Int Immunol 2004, 16:241-7.

33. Elgueta R, Benson MJ, de Vries VC, Wasiuk A, Guo Y, Noelle RJ: Molecular mechanism and function of CD40/CD40L engagement in the immune system. Immunol Rev 2009, 229:152-72.

34. Hornung M, Lindemann D, Kraus C, Peters A, Berberich I: The CD40 TRAF family member interacting motif carries the information to rescue WEHI 231 cells from anti-IGM-induced growth arrest. Eur J Immunol 1998, 28:3812-23.

35. Falschlehner C, Ganten TM, Koschny R, Schaefer U, Walczak H: TRAIL and Other TRAIL Receptor Agonists as Novel Cancer Therapeutics. Adv Exp Med Biol 2009, 647:195-206.

36. Nyambayar D, Iwabuchi K, Hedlund E, Murakawa S, Shirai K, Iwabuchi C, Kon $Y$, Miyazaki $Y$, Yanagawa Y, Onoe K: Characterization of NKT-cell hybridomas expressing invariant T-cell antigen receptors. J Clin Exp Hematop 2007, 47:1-8.

37. Schoenborn JR, Wilson CB: Regulation of interferon-gamma during innate and adaptive immune responses. Adv Immunol 2007, 96:41-101. 
38. Kronenberg M: Toward an understanding of NKT cell biology: progress and paradoxes. Annu Rev Immunol 2005, 23:877-900

39. Steinman $L$ : A brief history of $T(H) 17$, the first major revision in the $T(H)$ $1 / T(H) 2$ hypothesis of T cell-mediated tissue damage. Nat Med 2007, 13:139-45.

40. Mills KH: Induction, function and regulation of IL-17-producing T cells. Eur J Immunol 2008, 38:2636-49.

41. Sakaguchi S, Sakaguchi N, Asano M, Itoh M, Toda M: Immunologic selftolerance maintained by activated T cells expressing IL-2 receptor alphachains (CD25). Breakdown of a single mechanism of self-tolerance causes various autoimmune diseases. J Immunol 1995, 155:1151-64.

42. Suri-Payer E, Amar AZ, Thornton AM, Shevach EM: CD4+CD25+ T cells inhibit both the induction and effector function of autoreactive $T$ cells and represent a unique lineage of immunoregulatory cells. $J$ Immunol 1998, 160:1212-8.

43. Shevach EM: Certified professionals: CD4(+)CD25(+) suppressor T cells. J Exp Med 2001, 193:F41-6.

44. Papiernik M, de Moraes ML, Pontoux C, Vasseur F, Penit C: Regulatory CD4 T cells: expression of IL-2R alpha chain, resistance to clonal deletion and IL-2 dependency. Int Immunol 1998, 10:371-8.

45. Glimcher LH, Townsend MJ, Sullivan BM, Lord GM: Recent developments in the transcriptional regulation of cytolytic effector cells. Nat Rev Immunol 2004, 4:900-11.

46. Pearce EL, Mullen AC, Martins GA, Krawczyk CM, Hutchins AS, Zediak VP, Banica M, DiCioccio CB, Gross DA, Mao CA, et al: Control of effector CD8+ T cell function by the transcription factor Eomesodermin. Science 2003, 302:1041-3.

47. Kassiotis G, Gray D, Kiafard Z, Zwirner J, Stockinger B: Functional specialization of memory Th cells revealed by expression of integrin CD49b. J Immunol 2006, 177:968-75.

doi:10.1186/1471-2172-12-26

Cite this article as: Werner et al:: DX5 ${ }^{+} \mathrm{NKT}$ cells display phenotypical and functional differences between spleen and liver as well as NK1.1 Balb/c and NK1.1 ${ }^{+}$C57BI/6 mice. BMC Immunology 2011 12:26.

\section{Submit your next manuscript to BioMed Central and take full advantage of:}

- Convenient online submission

- Thorough peer review

- No space constraints or color figure charges

- Immediate publication on acceptance

- Inclusion in PubMed, CAS, Scopus and Google Scholar

- Research which is freely available for redistribution

Submit your manuscript at www.biomedcentral.com/submit 